This item was submitted to Loughborough's Institutional Repository (https://dspace.lboro.ac.uk/) by the author and is made available under the following Creative Commons Licence conditions.

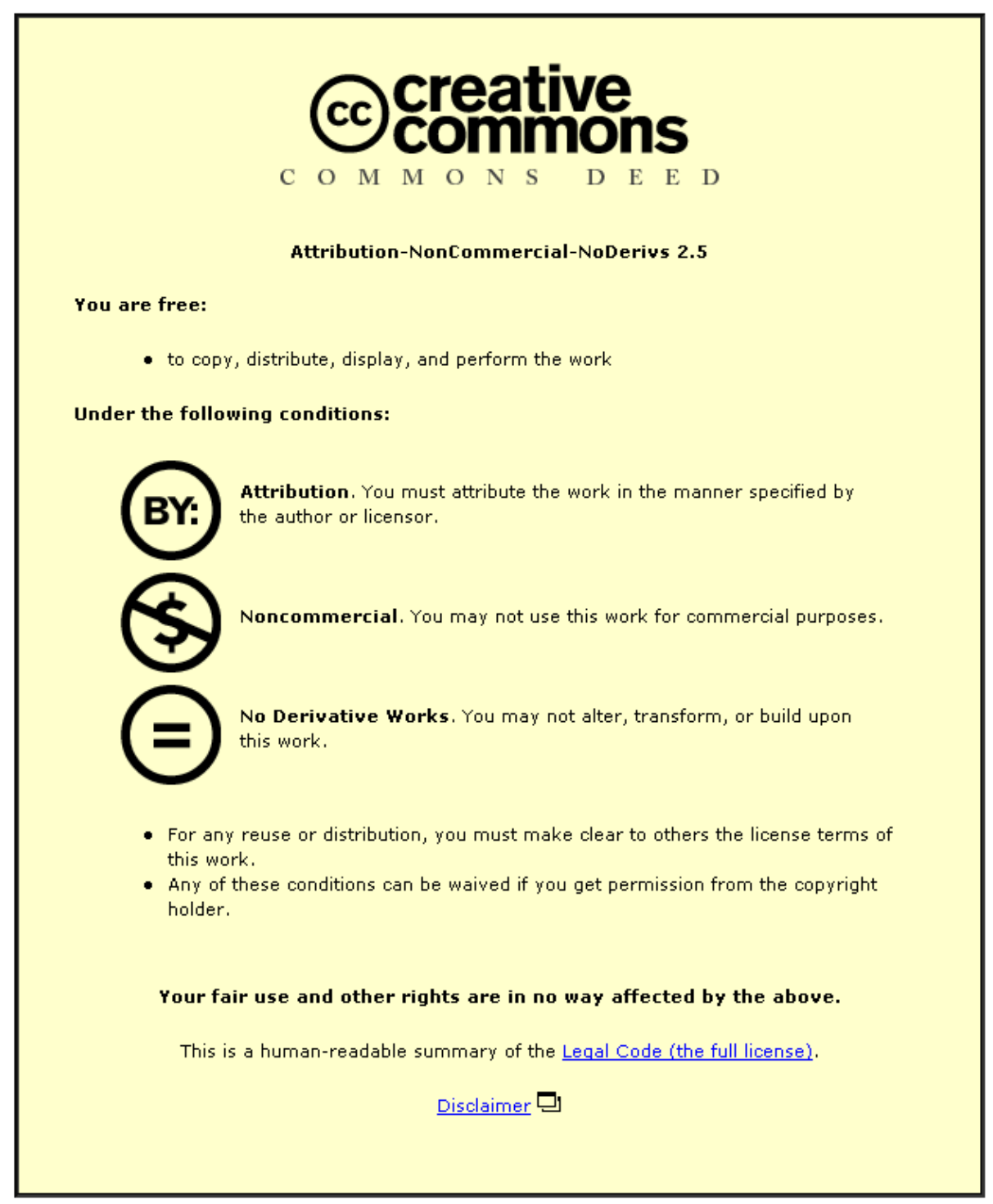

For the full text of this licence, please go to: http://creativecommons.org/licenses/by-nc-nd/2.5/ 


\title{
EVALUATION AND COMPARISON OF PROTEIN ULTRAFILTRATION TEST RESULTS: DEAD- END STIRRED CELL COMPARED WITH A CROSSFLOW SYSTEM
}

\author{
N.O. Becht, D.J. Malik and E.S. Tarleton \\ Advanced Separations Technologies Group, Department of Chemical Engineering, Loughborough \\ University, Loughborough, Leicestershire, LE11 3TU, UK.
}

\begin{abstract}
Dead-end stirred cell devices are commonly used in laboratories to characterise ultrafiltration membranes and their separation behaviour. Additionally, protein separation data from such systems are used for process scale-up. Such devices are operated under conditions that are inherently different from those used during the continuous or semi-continuous processing of industrial feed streams. The work presented in this paper compares the rejection behaviour of single protein solutions in both a dead-end stirred cell (SC) device with that for a crossflow system $(\mathrm{CF})$. The effect of ionic strength $(20 \mathrm{mM}$ and $100 \mathrm{mM})$ and solution $\mathrm{pH}(4.9,6.0,7.1,8.4$ and 11.0) on protein filtration (bovine serum albumin (BSA) and lysozyme (LYZ) from buffered aqueous solutions) behaviour has been investigated using polyethersulfone (PES) membranes with a manufacturer specified molecular weight cut-off (MWCO) of $50 \mathrm{kDa}$. PES membranes were characterised in terms of dextran MWCO using both the SC and the CF systems. The mode of operation resulted in significant observed differences in the resulting dextran solute rejection curves for the two systems. The observed rejection $\left(R_{\text {obs }}\right)$ values for a series of dextran standards were consistently found to be lower for the CF system compared with the SC unit suggesting higher wall concentrations $\left(C_{w}\right)$ due to concentration polarisation effects in the CF unit. Protein ultrafiltration studies with the $50 \mathrm{kDa}$ PES membranes highlighted important differences in observed protein rejection behaviour despite operation of the two systems at the same transmembrane pressures $(25 \mathrm{kPa})$. Solution $\mathrm{pH}$ was found to have little effect on the rejection of both $B S A$ and $L Y Z$. The solute rejection was found to be more sensitive to ionic strength effects for the SC device both during BSA and LYZ filtration. Convective mass transfer coefficients and hence the true rejection coefficients $\left(R_{t r}\right)$ were calculated for both systems using the stagnant film model to understand the influence of hydrodynamic effects on the ultrafiltration behaviour of the two systems. The magnitude of the Peclet number $(\mathrm{Pe})$ provides a means of comparing hydrodynamic conditions for the two systems and thereby allows differences in observed solute rejection to be better understood.
\end{abstract}

\section{KEYWORDS}

Stagnant film model; Ultrafiltration; Crossflow; Stirred-cell; Proteins

\section{INTRODUCTION}

Ultrafiltration finds wide application in diverse industries such as the pharmaceutical, bio-medical and food industries where separation is predominantly controlled on the basis of molecular size differences although solution $\mathrm{pH}$, ionic strength and system hydrodynamics have been acknowledged to play a role in the separation of proteins [1-6]. Saksena and Zydney [5] demonstrated the importance of electrostatic interactions on protein filtration when attempting to separate bovine serum albumin (BSA) from immunoglobulin (IgG) using an Amicon stirred ultrafiltration cell. The authors [5] carefully selected solution $\mathrm{pH}$ and ionic strength thereby creating the possibility to transport more of the larger IgG through a $100 \mathrm{kDa}$ polymeric membrane compared to the smaller albumin molecule, a phenomenon termed 'reversed selectivity'. In a later study, Eijndhoven et al. [6] also demonstrated that it is, in fact, possible to separate molecules of a similar size with ultrafiltration thereby challenging the general understanding that ultrafiltration is only suited to the separation of molecules having at least two to three orders of magnitude 
difference in size. The same authors [6] also pointed out that the degree of separation can be improved with a crossflow device (as compared to a stirred cell) which they attributed to a higher bulk mass transfer rate. Evidence from previous studies suggests that solution ionic strength influences the extent of charge interaction in terms of protein-protein and protein-membrane interactions. Several researchers have demonstrated the influence of ionic strength on permeate flux. Solution $\mathrm{pH}$ has been shown to have less of an effect at higher ionic strengths [6-9]. Whilst sufficient evidence exists in the literature to demonstrate the importance of electrostatic interactions $[1,4,9,10]$ there still seem to be differing observations concerning permeate flux and rejection at and around the pl of the protein.

A review of recent literature found little published work comparing ultrafiltration measurements made at the laboratory scale (usually, researchers seem to employ a dead-end stirred cell apparatus) and how such results correlate with those from process scale measurements (typically crossflow semi-continuous/continuous systems) [11-13]. This is surprising, given that hydrodynamic conditions (such as wall shear rates and convective mass transfer coefficients facilitating rejected solute back-mixing, etc.) can have a noticeable impact on ultrafiltration filtration and such conditions are known to vary with membrane configuration [14]. It is particularly noticeable that the experimental basis for comparison of various membrane modules in terms of the system hydrodynamics (Reynolds number, module surface shear, etc.) and general operating conditions such as feed concentration, $\mathrm{pH}$ etc. have received little attention. It is necessary to provide more experimental detail of such parameters if an informative comparison between two different membrane configurations is to be made. Tansel et al. [13], for example, compared ion permeability data from nanofiltration experiments for both dead-end (using a stirred cell) and crossflow modes but did not describe the basic conditions of their comparison. This made it difficult for the reader to draw conclusions from their findings. More recently Zydney and Xenopoulos [15] pointed out that the effects of device configuration and operational parameters, particularly for dextran characterisation experiments, are still poorly understood. They compared solute rejection data for a stirred cell and a crossflow system and stated that the stirred cell provides more accurate dextran rejection data which they attributed to better flux uniformity and the reduced influence of concentration polarisation due to higher convective mass transfer rates in the stirred cell system.

In the current work protein ultrafiltration with BSA and lysozyme (LYZ) was studied using a Millipore stirred cell (XFUF4701) and a specially designed crossflow device. Each protein was studied at four different $\mathrm{pH}$ values $(4.9,6.0,7.1,8.4)$ and two different ionic strengths $(20 \mathrm{mM}$ and $100 \mathrm{mM})$. Due to the high isoelectric point of $\mathrm{LYZ}(\mathrm{pH} \mathrm{11.0),} \mathrm{lysozyme} \mathrm{ultrafiltration} \mathrm{at} \mathrm{pH} 11.0$ was also conducted at both ionic strengths using the stirred cell. The ultrafiltration data are discussed in terms of the effects of solution $\mathrm{pH}$ and ionic strength as well as effects of convective mass transfer in the stirred cell and crossflow devices. These were found to show marked differences in the observed ultrafiltration results under commonly controlled experimental conditions such as the trans-membrane pressure.

\section{EXPERIMENTAL}

\section{Materials}

Polyethersulfone (PES) membranes with MWCO of 50 kDa were supplied by Microdyn-Nadir $\mathrm{GmbH}$, Germany. These membranes are described by the manufacturer as hydrophilic, with strong chemical stability and carry a minimal negative charge over the $\mathrm{pH}$ range studied (4.9 to 11.0). Lysozyme (MW $14.3 \mathrm{kDa}, 11.0 \mathrm{pl}$ ) and Bovine Serum Albumin (MW 66.4 kDa, 4.7-4.9 pl) were purchased from Sigma-Aldrich (UK) Ltd. PES membranes with a $50 \mathrm{kDa}$ cut-off were chosen deliberately since it was desirable for some of the BSA to potentially transmit through the membrane. In order to carry out MWCO studies dextran standards with narrow polydispersity and molecular weights of 1, 5, 12, 25, 50 and $150 \mathrm{kDa}$ were obtained from Polymer Standards Services $\mathrm{GmbH}$, Germany. 


\section{Preparation}

For all experiments deionised water with a resistivity of at least $18.2 \mathrm{M} \Omega \mathrm{cm}$ was used. All membranes were pretreated prior to their first use according to a set procedure, a methodology which was developed through experience from previous experiments with a range of different PES membranes. This included storage of the membranes for $24 \mathrm{~h}$ in deionised water followed by 30 mins. storage in $0.1 \mathrm{M} \mathrm{NaOH}$. Subsequently, the membranes were flushed with water at $50 \mathrm{kPa}$ trans-membrane pressure for at least 60 mins. in order to remove any residual agents from the manufacture. Permeation at this elevated pressure also helped to prevent any membrane compaction effects when conducting subsequent water flux and solute flux measurements at 25 $\mathrm{kPa}$. Water flux measurements were made for each membrane sample over a $1 \mathrm{~h}$ period. Single protein solutions for BSA and LYZ were prepared in phosphate buffer with 20 and $100 \mathrm{mM}$ ionic strength, respectively. LYZ solution was also prepared at $\mathrm{pH} 11.0$ for stirred cell experiments in a glycine buffer ( $\mathrm{pK}_{\mathrm{a}}$ closer to the protein $\left.\mathrm{pl}\right)$. All buffer solutions were pre-filtered to remove any potential aggregates and un-dissolved proteins from the solution using $0.45 \mu \mathrm{m}$ nylon membranes (Whatman plc, UK). The concentrations of both BSA and LYZ were determined using a UV/vis spectrophotometer (Lambda 12, Perkin-Elmer) at $280 \mathrm{~nm}$ and evaluated against predetermined calibration curves.

\section{Membrane Filtration Apparatus}

Two membrane configurations were employed. The Millipore stirred cell (Model XFUF04701) had a diameter of $47 \mathrm{~mm}$ and an effective membrane area of $15 \mathrm{~cm}^{2}$. The cell was operated with a stirrer speed of $2400 \mathrm{rpm}$ as determined using a phototachometer (Model TM-3011). The feed volume was fixed at $50 \mathrm{~mL}$. This device was operated by pressurising the head space in the stirred cell using nitrogen from a gas cylinder as shown in Figure 1.

The crossflow apparatus incorporated a flat sheet membrane placed within the rectangular flow channel (see Figure 2). The module was designed in a manner that allowed the fluid flow profile to develop inside the channel before the feed reached the membrane. The crossflow apparatus had a feed volume of $1 \mathrm{I}$ and the membrane area was $7.1 \mathrm{~cm}^{2}$. The apparatus, constructed from stainless steel, comprised of a feed tank from which the feed was supplied to the membrane module via a diaphragm pump (Jabsco, Model 31800). The retentate was recycled continuously to the feed tank whilst permeate was either sampled and/or returned to the feed tank. The system was equipped with calibrated pressure transducers (upstream, at the entrance and downstream, at the exit of the membrane module) linked to a digital pressure display to monitor the pressure drop across the membrane module. The pressure gauges for the stirred cell and the crossflow module were calibrated. All experiments were conducted at a temperature of $22^{\circ} \mathrm{C}\left( \pm 2^{\circ} \mathrm{C}\right)$.

Each experiment was performed with a new, clean membrane sample, pretreated in the manner mentioned earlier. Protein filtration experiments were conducted for 30 mins. using the stirred cell and for at least $2 \mathrm{~h}$ using the crossflow apparatus; samples were taken at regular intervals. Protein filtration with the stirred cell device was conducted over a shorter time period because of system limitations such as the restricted feed volume. All filtrate samples were corrected for hold-up volume and sampled accordingly. In the case of the stirred cell, the feed sample was obtained immediately after taking the filtrate sample by opening the stirred cell. The feed sample of the crossflow apparatus could be readily obtained from the retentate line.

\section{Membrane Characterisation}

The molecular weight cut-off (MWCO), defined as the membrane cut-off at which $90 \%$ of the molecule with the same molecular weight as that specified by the membrane manufacturer is retained, was evaluated using dextran standards with narrow polydispersity. As mentioned previously, the standards ranged from 1 to $150 \mathrm{kDa}$ relative molecular mass. 


\section{THEORY}

\section{Determination of Reynolds Number for the SC and the CF Units}

The Reynolds number in the crossflow module $\left(\operatorname{Re}_{c f}\right)$ was determined in the same manner as for fluid flow in a duct since the flow channel is rectangular, whereas in the case of the stirred cell, the flow regime is determined from the rotational Reynolds number $\left(\operatorname{Re}_{i}\right)$ as given by equations (1) and (2), respectively.

$$
\mathrm{Re}_{c f}=\frac{\rho u D_{h}}{\mu}
$$

$\mathrm{Re}_{r}=\frac{\rho \omega r_{t}^{2}}{\mu}$

where $\rho$ is the fluid density, $u$ the crossflow velocity (maintained at $0.42 \mathrm{~m} / \mathrm{s}$ ), $D_{h}$ the hydraulic diameter, $\mu$ the dynamic viscosity, $\omega$ the angular velocity and $r_{t}$ the radius of the stirred cell.

\section{Determination of Shear Stress}

The difficulty in making a direct comparison between a stirred cell and a crossflow module arises from the need to match hydrodynamic conditions in each system. Ideally, not only the shear at the membrane surface ought to be the same but all other parameters (e.g. the solvent velocity normal to the membrane surface) also need to be equal. In this work the trans-membrane pressure, temperature, feed concentration, $\mathrm{pH}$ and ionic strength were all maintained at fixed levels during the experiments with the crossflow and stirred cell devices.

It has previously been shown impracticable to compare the impeller Reynolds number in the stirred cell (laminar flow up to $\mathrm{Re}<10$ ) with the Reynolds number for the crossflow module (laminar flow up to $\operatorname{Re} \sim 2100$ ) [16]. In other words, a comparison of the two apparatus on the basis of liquid mixing and flow profile is inadequate. Instead, an attempt was made to select operating conditions in a manner that allowed similar shear stress conditions to be maintained at the membrane surface. A force balance across the crossflow membrane module depicted in Figure 3 gives:

$$
a b \Delta P=2 T L(a+b)
$$

where $a$ is the channel width, $b$ the channel height, $L$ the membrane length, $\Delta P$ the pressure drop across the membrane length and $\tau$ the shear stress. Solving for the shear stress $\tau$ and including the hydraulic diameter of the membrane channel yields:

$$
T=\frac{\Delta P D_{h}}{4 L}
$$

The pressure drop across the membrane length (based on a constant $\Delta P$ across the entire membrane module) is calculated as $110 \mathrm{~Pa}$ and including the module dimensions a wall shear stress of $34 \mathrm{~Pa}$ is determined for the crossflow apparatus (using equation (4)).

Determination of the shear stress in the stirred cell device is more difficult. To enable calculations the stirrer in the Millipore cell was assumed to resemble a flat blade paddle impeller and the flow field was subdivided into an inner region (where the shear stress increases up to the critical radius of the impeller) and an outer region beyond which the shear stress decreases again (see Figure 4); such a procedure has previously been used to compare oil droplet formation in a Weissenberg rheometer and a stirred cell [17]. The correlations (given below) are for the flow-field approximated 
as a rigid-body rotation above a stationary surface (Bodewadt flow). The maximum shear stress is experienced at the critical radius $\left(r_{c}\right)$ of the impeller which is given by:

$r_{c}=\frac{D_{i}}{2} 1.23\left(0.57+0.35 \frac{D_{i}}{D_{t}}\right)\left(\frac{h}{D_{t}}\right)^{0.036} n_{b}^{0.116} \frac{\mathrm{Re}_{i}}{1000+1.43 \operatorname{Re}_{i}}$

where $D_{t}$ is the stirred cell diameter, $h$ the blade height, $n_{b}$ corresponds to the number of stirrer blades and $\mathrm{Re}_{i}$ the impeller Reynolds number as defined by equation (2) except that the lengthscale used in the equation is the impeller diameter rather than the tank diameter. For the Millipore stirred cell $D_{i}=3.8 \mathrm{~cm}, W=4.2 \mathrm{~cm}, b=0.9 \mathrm{~cm}$, and $n_{b}=2$. The shear stress at the critical radius was calculated to be $48 \mathrm{~Pa}$ using equation (5) whereas the shear stress below and above the critical radius was calculated using equations (6) and (7), as defined by Kosvintsev et al. [17], such that

$$
\begin{array}{ll}
T=0.825 \mu \omega r \frac{1}{\delta} & r<r_{c} \\
T=0.825 \mu \omega r_{c}\left(\frac{r_{c}}{r}\right)^{0.6} \frac{1}{\delta} & r>r_{c}
\end{array}
$$

and the thickness of the momentum boundary layer $(\delta)$ is obtained from the relationship between the momentum boundary layer $(\delta)$ and the concentration boundary layer $\left(\delta_{C}\right)$ given as [18]

$$
\frac{\delta}{\delta_{C}}=S c^{0.33}
$$

The concentration boundary layer $\left(\delta_{C}\right)$ here was evaluated using the Landau-Lifshitz equation [19]:

$$
\delta_{C}=\frac{D_{i}}{S c^{1 / 3} \sqrt{\operatorname{Re}_{r}}}
$$

Combining (8a) and (8b) gives the momentum boundary layer thickness $(\bar{\delta})$ used in equations (6) and (7):

$$
\delta=\sqrt{\frac{\mu}{\rho \omega}}
$$

The critical radius for the impeller in the Millipore cell was determined as $1.47 \mathrm{~cm}$ for the forced impeller speed of $2400 \mathrm{rpm}$ which corresponds to the maximum speed that can be achieved with the stirrer ensuring that the depth of the vortex created by the impeller does not become too large. Moreover, an increase in the stirrer speed beyond this level does not further impact on the position of the critical radius. An average shear stress across the impeller was obtained by integration of equations (6) and (7). A stirred speed of $2700 \mathrm{rpm}$ results in an average shear stress of $34 \mathrm{~Pa}$, i.e. equal to that in the crossflow module, but limited by no further increase in the critical radius.

However, with the experimental conditions used it was only possible to achieve a maximum stirrer speed of $2400 \mathrm{rpm}$, i.e. $T=29 \mathrm{~Pa}$. This lower rpm corresponds to an error in the average shear stress of circa $15 \%$, but it represents the closest match that could be obtained whilst still maintaining the values of other process variables.

\section{Determination of Mass Transfer Coefficients}


During ultrafiltration, the retained solute concentration close to the membrane wall increases with respect to the bulk concentration. Thus, facilitation of back diffusion of solute is important in determining the solute rejection and the limiting permeate flux for a given process. Under ideal comparison conditions, in addition to the other parameters, the mass transfer coefficients should also be identical in the two filtration systems in question. The mass transfer coefficient is the ratio of the diffusion coefficient of the solute to the concentration boundary layer $\left(\delta_{C}\right)$. The diffusion coefficients, $D_{s}$, for BSA and LYZ can be determined from the Stokes-Einstein equation, this also allows one to take account of the influence of ionic strength (e.g. by evaluating the Debye layer thickness as a function of ionic strength, discussed below). The effective size of BSA was found by Pujar and Zydney [20] to vary linearly with the Debye length (i.e. inversely with the square root of the solution ionic strength). The magnitude of the Debye length, $\lambda_{D}$, a measure of the extent of the charge layer around a molecule in an electrolyte solution, can be calculated using equation (9):

$$
\lambda_{D}=\sqrt{\frac{\varepsilon_{0} \varepsilon_{r} k_{B} T}{2 N_{A} e^{2} l}}
$$

where $\varepsilon_{0}$ is the permittivity of free space, $\varepsilon_{r}$ the dielectric constant, $k_{B}$ the Boltzmann constant, $N_{A}$ Avogadro's number, $e$ the elementary charge and $/$ the ionic strength of the electrolyte. From equation (9) the Debye length, $\lambda_{D}$, for the two ionic strengths employed in this work was $2.15 \mathrm{~nm}$ $(20 \mathrm{mM})$ and $0.96 \mathrm{~nm}(100 \mathrm{mM})$, respectively. The influence of $\mathrm{pH}$ on the number of charges at the protein surface has not been considered here. To incorporate the effect of the Debye length, it is added to the protein radius and an effective hydrodynamic radius of the protein is obtained, which includes the thickness of the charged double layer around the protein. Therefore, using the Stokes-Einstein equation [21], different diffusion coefficients may be calculated based on the ionic strength difference:

$$
D=\frac{k_{B} T}{6 \pi \mu r_{s}}
$$

where $r_{s}$ is the solute radius. Based on a Stokes radius of $3.2 \mathrm{~nm}$ the evaluated diffusion coefficients for BSA were $4.0 \times 10^{-11} \mathrm{~m}^{2} / \mathrm{s}(20 \mathrm{mM})$ and $5.2 \times 10^{-11} \mathrm{~m}^{2} / \mathrm{s}(100 \mathrm{mM})$. For a Stokes radius of $1.9 \mathrm{~nm}$ the evaluated diffusion coefficients for $L Y Z$ were $5.3 \times 10^{-11} \mathrm{~m}^{2} / \mathrm{s}(20 \mathrm{mM})$ and $7.6 \times 10^{-11} \mathrm{~m}^{2} / \mathrm{s}(100 \mathrm{mM})$. The diffusion coefficient for $L Y Z$ is higher than that for BSA as LYZ is a smaller molecule. The diffusion coefficients were used to calculate the mass transfer coefficient in both the stirred cell and crossflow device using typical mass transfer correlations. The mass transfer coefficient, $k_{m}$, in the stirred cell was obtained from the following Sherwood, Sh, correlation [22]:

$$
\left(\frac{k_{m} r_{t}}{D_{s}}\right)=S h=0.27 \operatorname{Re}_{r}^{0.567} S c^{0.33}
$$

where $r_{t}$ is the radius of the stirred cell. The mass transfer coefficient in the crossflow system can be obtained from the Graetz-Leveque relationship [23], which is applicable to laminar flow in channels:

$k_{m}=0.816\left(\frac{V}{L_{c}} D_{s}^{2}\right)^{1 / 3}$

An alternative equation (12b) [23] that is similar in form to that for the SC equation (11) also gave similar orders of magnitude mass transfer coefficients for the CF system: 
$\left(\frac{k_{m} D_{h}}{D_{s}}\right)=S h=0.04 \operatorname{Re}^{0.75} S c^{0.33}$

In equation (12a), $\gamma$ is the fluid shear rate at the membrane surface and $L_{c}$ the channel length. Thus, the mass transfer coefficient and hence the limiting solvent flux would be expected to vary as the cube root of the wall shear rate as shown by Blatt [23]. The fluid shear rate for a rectangular channel can be obtained from:

$v=\frac{6 u}{b}$

where $b$ is the channel height. The calculated wall shear rate $\gamma_{w}$ for a crossflow velocity of 0.42 $\mathrm{m} / \mathrm{s}$ corresponds to $1260 \mathrm{~s}^{-1}$. Using Newton's law of viscosity, wall shear stress is only $1.3 \mathrm{~Pa}$. The difference between the calculated and the measured significant pressure drop due to entry and exit effects results in higher measured values of the pressure drop and hence wall shear stress values.

The membrane Peclet number $\left(\mathrm{Pe}_{m}=J \delta_{C} D_{s}\right)$ provides a comparison of the relative magnitudes of diffusion and convection. In the present study evaluation of the $\mathrm{Pe}_{m}$ for the SC and CF has been undertaken.

\section{RESULTS AND DISCUSSION}

\section{Membrane Characterisation}

It is generally accepted that the structure and crosslinking of asymmetric, polymeric membranes can vary from lot-to-lot. Moreover, it is also not uncommon to find slight variations in the membrane pore structure for membranes cut from the same sheet. For this work 32 samples of PES membranes were characterised in terms of their water flux at a constant operating transmembrane pressure of $25 \mathrm{kPa}$ in the stirred cell and crossflow apparatus (16 samples were studied in each setup). Two observations were made: (1) the water flux was higher in the crossflow apparatus compared to the stirred cell and (2) the water flux variation around the mean was slightly higher in the stirred cell system compared to the crossflow system. As can be seen in Figure 5 the average flux of pure water for 16 different membrane samples was approximately $100 \mathrm{~L} / \mathrm{m}^{2} \mathrm{~h}$ for the crossflow system compared with $80 \mathrm{~L} / \mathrm{m}^{2} \mathrm{~h}$ for the stirred cell device. The higher flux in the crossflow system is due to the lower hydraulic resistance of the membrane supporting base plate design (base plate permeability without membrane, $L_{s, C F}=1.5 \times 10^{-11} \mathrm{~m}$ ) compared with the base plate permeability for the $S C$ system $\left(L_{s, S C}=1.9 \times 10^{-12} \mathrm{~m}\right)$. The overall solvent permeability for the $50 \mathrm{kDa}$ membrane was for the CF $\left(L_{p, C F}=1.1 \times 10^{-12} \mathrm{~m}\right)$ and for the SC $\left(L_{p, S C}=8.9 \times 10^{-13} \mathrm{~m}\right)$ respectively. Fluctuations in the solvent (water) flux were slightly higher for the stirred cell (up to $\pm 7 \%$ ) compared with data for the crossflow apparatus (up to $\pm 5 \%$ ).

Ultrafiltration membranes are typically characterised by the nominal molecular weight cut-off (MWCO) defined as the molecular weight of a solute (usually low polydispersity dextrans or polyethylene glycols) that has a rejection coefficient of $90 \%$. Dextran solute rejection measurements (using a range of dextran molecular weights) were used to characterise the solute rejection behaviour of $50 \mathrm{kDa}$ PES membranes. Data were obtained for both the stirred cell and the crossflow apparatus at a constant trans-membrane pressure of $25 \mathrm{kPa}$. It is immediately obvious from the data in Figure 6 , that dextran rejection with the crossflow system was generally lower than for the stirred cell device. This result may be explained in terms of concentration polarisation effects (see calculated values of mass transfer coefficients for the dextrans in Table 1). Thus accumulation of the completely or partially rejected solutes close to the membrane surface results in a higher wall concentration $\left(C_{w}\right)$ of the solute for the CF system. For the crossflow system, tangential flow of the fluid results in a continuous regeneration of any concentration 
polarisation at the device inlet. The observed lower rejection of dextrans using the crossflow apparatus suggests that concentration polarisation effects were higher in comparison to the stirred cell. Calculation of the true rejection coefficients (based on the calculated solute wall concentration) using the stagnant film model for the protein filtration results supports this hypothesis. Permeate flux data for dextran standard solutions were found to be higher for the crossflow module compared to the stirred cell system; permeate flux was approximately $20 \mathrm{~L} / \mathrm{m}^{2} \mathrm{~h}$ higher for the crossflow apparatus compared to the stirred cell (similar to water flux data reported in Figure 5).

It is interesting to note that the manufacturer quoted MWCO for the PES membranes (50 kDa) correlates well with dextran solute rejection data obtained using the stirred cell device (see Figure 6). However, the MWCO value based on dextran rejection measurements with the crossflow apparatus would put the value close to $75 \mathrm{kDa}$. This is of some importance in selecting membranes to separate proteins or to retain them (e.g. to swap buffers in biotechnological applications). For dextrans and proteins, an equivalent hard sphere radius, $r$ (estimated using the Stoke's-Einstein equation) results in simple correlations for the dextran $(\AA)$ and protein radius (nm) respectively as a function of the protein molecular weight (MW):

For dextrans, the following correlation by Granath and Kvist [24] allows for the calculation of the dextran radius:

$r=0.33(M W)^{0.46}$

where the radius $(r, \AA)$ and the molecular weight ( $\mathrm{MW}, \mathrm{g} / \mathrm{mol})$. For proteins, the correlation by Squire [25] may be used:

$r=0.794(M W)^{1 / 3}$

where the radius $(r, \mathrm{~nm})$ and the molecular weight $(\mathrm{MW}, \mathrm{kg} / \mathrm{mol})$.

Table 1 provides Stoke's radii for the calibration dextrans, BSA and LYZ used in the present study. Comparison of the Stoke's radii for a $50 \mathrm{kDa}$ dextran ( $r=4.8 \mathrm{~nm}$, using the correlation above) would suggest that a $50 \mathrm{kDa}$ MWCO PES membrane would not be well suited to reject a protein such as BSA (MW $66.4 \mathrm{kDa}$ and $r=3.2 \mathrm{~nm}$ ). The MWCO value of $75 \mathrm{kDa}$ obtained from the dextran solute rejection measurements using the crossflow system suggests $90 \%$ rejection of solutes with an equivalent Stoke's radius of $5.8 \mathrm{~nm}$ (determined using equation (14)). Under the operating conditions used to take the solute rejection data, the $\mathrm{Pe}_{m}$ for the $12.5 \mathrm{kDa}$ dextran was around 0.7 for the SC system compared with 4.2 for the CF system. The higher $\mathrm{Pe}_{m}$ for the CF system results in a higher solute concentration at the membrane surface. This results in a lower observed solute rejection, $R_{\text {obs }}$. In industrial applications, the leakage of solute is a problem and to prevent this from happening, it is common practise to select a membrane with a significantly lower MWCO in order to ensure complete rejection of the solute. A more meaningful characterisation of the MWCO for the membrane to be used in a crossflow system would need to allow careful control of the testing conditions, e.g. by ensuring that the system Peclet number for the SC system is kept of the same order as that to be used in the CF unit. Thus, a more conservative selection of the membrane for a given application may be possible.

\section{Protein Filtration Results}

All filtration experiments were carried out with a protein concentration of $0.5 \mathrm{~g} / \mathrm{L}$. In the crossflow module the crossflow velocity was $0.42 \mathrm{~m} / \mathrm{s}$ and the flow profile was laminar (corresponding Reynolds number of 1560 , determined by equation (1)). The rotational Reynolds number in the stirred cell (determined by equation (2)) at a stirrer speed of $2400 \mathrm{rpm}$ was 57,000 where the flow is turbulent. Whilst liquid mixing is different under these conditions the shear stress experienced at the membrane surface is similar to that experienced in the crossflow system, i.e. in the range of 29 
to $34 \mathrm{~Pa}$. In Figures $7-10$ both flux and protein observed rejection data versus $\mathrm{pH}$ are shown for two different ionic strengths (20 and $100 \mathrm{mM}$ ). The maximum filtration time in the crossflow experiments was $2 \mathrm{~h}$ and 30 mins. with the stirred cell. In order to allow for a more appropriate comparison between the two membrane configurations all flux and rejection data shown in Figures 7-10 are those obtained after 30 mins. Error bars are not shown in order to aid clarity, however, the maximum percentage error at any flux or rejection data point was calculated to be less than $\pm 2 \%$.

Data for $B S A$ and $L Y Z$ rejection and permeate flux at the various $\mathrm{pH}$ values and the two different ionic strengths are depicted in Figs. 7-10 and general observations are summarised in Table 2. The most obvious finding relates to the influence of solution ionic strength effects on protein rejection (for the stirred cell system) which are generally more pronounced than $\mathrm{pH}$ effects. The crossflow system showed BSA rejection by the $50 \mathrm{kDa}$ PES membrane to be greater than $85 \%$ and almost invariant to the measurements obtained at the low $(20 \mathrm{mM})$ and the high $(100 \mathrm{mM})$ ionic strength values. BSA rejection for both the crossflow and the stirred cell systems were found to be $\mathrm{pH}$ invariant. However, the stirred cell system displayed greater transmission of BSA compared with the crossflow system. Additionally, BSA rejection was found to be higher at the high ionic strength $(100 \mathrm{mM})$ compared with BSA rejection data obtained at $20 \mathrm{mM}$. These effects were not seen for the crossflow system. Additionally, the permeate flux for the SC was slightly higher than for the CF system. During water permeability measurements, the CF system had a higher solvent permeability (almost $25 \%$ higher).

The observed rejection of LYZ was found to be higher for the lower ionic strength data (mainly for the data obtained using the stirred cell system). LYZ rejection was found to be mainly $\mathrm{pH}$ invariant except at $\mathrm{pH} 5$ when a marked increase in LYZ rejection was noted. The effect of $\mathrm{pH}$ was more pronounced at the lower ionic strength $(20 \mathrm{mM})$ but still apparent for data recorded at the higher ionic strength $(100 \mathrm{mM})$. This was found to be the case for data obtained using both the stirred cell and the crossflow systems, however, the effects were more noticeable during LYZ filtration using the SC. The permeate flux was found to be higher for the CF ( 25\%) compared with the SC system, mimicking water permeability results reported earlier.

In order to better explain the filtration results, the data were also analysed from a quantitative view point using the film model for concentration polarisation [23]. The model is based on a mass balance near the membrane wall and its integration over the concentration boundary layer $\left(\delta_{c}\right)$ yields the well known equation:

$J_{s}=\frac{D_{s}}{\delta_{c}} \ln \left(\frac{C_{w}-C_{p}}{C_{b}-C_{p}}\right)$

where $J_{s}$ is the solute flux, $C_{w}$ the concentration at the membrane surface, $C_{b}$ the bulk concentration and $C_{p}$ the concentration in the permeate. This equation is often rewritten in terms of the observed $\left(S_{o}=C_{p} / C_{b}\right)$ and the true or actual sieving coefficient $\left(S_{a}=C_{p} / C_{w}\right)$ [26].

$$
S_{a}=\frac{S_{o}}{\left(1-S_{o}\right) \exp \left(J_{s} / k\right)+S_{o}}
$$

In this work, the equation was expressed in terms of rejection coefficients, i.e. the actual or true rejection coefficient $\left(R_{t r}=1-C_{p} / C_{w}\right)$ was evaluated from the data for the observed rejection coefficient $\left(R_{o b s}=1-C_{p} / C_{f}\right)$ using equation (18):

$$
R_{t r}=\frac{R_{o b s}}{\left(1-R_{o b s} / \exp \left(J_{s} / k_{m}\right)\right)+R_{o b s}}
$$

\section{Protein Filtration of BSA}

Cite paper as: Becht N.O., Malik D.J. and Tarleton E.S., 2008, Evaluation and comparison of protein ultrafiltration test results: Deadend stirred cell compared with a crossflow system, Separation and Purification Technology, 62, 228-239. DOI: 
Figure 7 shows flux and rejection data for BSA filtration at both 20 and $100 \mathrm{mM}$ ionic strengths using the stirred cell. The data show BSA rejection ranging from 65 to $90 \%$ (rejection found to be influenced by the solution ionic strength, $65-75 \%$ rejection at $20 \mathrm{mM}$ and $85-90 \%$ rejection for measurements taken at $100 \mathrm{mM}$ ). The MWCO of the $50 \mathrm{kDa}$ PES membrane (refer to Figure 6, data for the SC) based on the dextran measurements obtained with the stirred cell suggests the cut-off for the membrane is $\sim 50 \mathrm{kDa}$ (Stoke's radius $4.8 \mathrm{~nm}$ ). Thus, the BSA rejection is higher than expected based on the dextran solute rejection data, provided the comparison is carried out using the Stoke's radii size comparison. Based on the relative molecular mass of BSA ( 66.4 kDa) and the calculated Stoke's radius of $3.2 \mathrm{~nm}$ alone, use of a membrane with a MWCO of $50 \mathrm{kDa}$ should result in BSA rejection of around $40 \%$ (for the stirred cell). The rejection is higher than this and suggests that due to a high surface charge density on the BSA molecule $(-13$ charges at $\mathrm{pH} 7)$ and low ionic strength $(20 \mathrm{mM})$ electrostatic effects result in a larger effective protein size resulting in a higher observed solute rejection. The larger size results in steric exclusion from pores of similar and smaller size thereby reducing overall transmission. At higher ionic strength, charge shielding may result in a reduction in the overall hydrodynamic size, however, this effect is more complicated due to the following: (i) smaller solute size may allow greater access to the membrane pores and may result in higher transmission, however (ii) smaller size also results in faster back diffusion into the bulk of the retentate fluid, thereby reducing the solute concentration at the wall and hence lower overall solute transport in the permeate. The calculated $\mathrm{Pe}_{m}$ for the SC system was $\sim 2(20 \mathrm{nM})$ and $\sim 1.5(100 \mathrm{mM})$. Higher $\mathrm{Pe}_{m}$ leads to higher solute wall concentrations and lower solute rejections (observed here).

The calculation of the Debye length for the two different ionic strengths results in the 'modified' Stoke's radius (i.e. including the Debye length) would either be $\sim 4.2 \mathrm{~nm}(100 \mathrm{mM}$ ) or $\sim 5.4 \mathrm{~nm}$ or $\sim 5.4 \mathrm{~nm}(20 \mathrm{mM})$. The calculated true rejection coefficients using equation (18) are presented in Table 3. The higher (almost complete rejection) values of the true rejection coefficients are a consequence of the higher calculated solute concentration at the membrane wall due to the phenomenon of concentration polarisation.

Figure 8 shows flux and rejection data for BSA filtration at both 20 and $100 \mathrm{mM}$ ionic strengths with the crossflow cell. The data in Figure 8 show BSA rejection ranging from 85 to $98 \%$ (rejection was found to be $\mathrm{pH}$ and ionic strength invariant). The MWCO of the $50 \mathrm{kDa}$ PES membrane (refer to Figure 6, CF data) based on the dextran measurements obtained with the crossflow cell suggests the cut-off for the membrane is $\sim 75 \mathrm{kDa}$ (Stoke's radius $5.8 \mathrm{~nm}$ ). Thus, the BSA rejection is again considerably higher than expected based on the dextran solute rejection data provided the comparison is carried out on the basis of steric hindrance using the Stoke's radii for comparison. The expected BSA rejection should be around $40 \%$ for the crossflow cell. The permeate flux measurements were found to be similar to those obtained for the stirred cell system suggesting accumulation of solute at the membrane surface resulting in increased hydraulic resistance to permeate flow. The permeate flux was found to be moderately higher $\left(70-80 \mathrm{~L} / \mathrm{m}^{2} \mathrm{~h}\right)$ at the lower ionic strength compared with $\left(55-70 \mathrm{~L} / \mathrm{m}^{2} \mathrm{~h}\right)$ for data measured at $100 \mathrm{mM}$. The calculated true rejection coefficient values are shown in Table 3 and suggest near complete rejection of BSA. The calculated $\mathrm{Pe}_{m}$ for the CF system was $\sim 7(20 \mathrm{mM})$ and $\sim 5(100 \mathrm{mM})$. The high values of $\mathrm{Pe}_{m}$ suggest the possibility of a secondary membrane fouling at the surface. The reduction in solvent flux (compared with the water permeability values) is evidence in support of this hypothesis. The higher wall concentration may result in a higher local viscosity of the protein solution excluding solvent flow through smaller pores. This may be the reason behind the higher observed BSA rejection values for the CF system.

\section{Protein Filtration of Lysozyme}

Lysozyme has a MW of $14.3 \mathrm{kDa}$ and a Stoke's radius of $1.9 \mathrm{~nm}$. On the basis of steric hindrance alone $L Y Z$ rejection behaviour would be similar to a dextran of size $\sim 7 \mathrm{kDa}$ ( $\sim 15 \%$ rejection). LYZ is also positively charged over the $\mathrm{pH}$ range studied (except at its isoelectric point $\sim \mathrm{pH} 11$ ) and the membrane carries a moderate negative surface charge at the $\mathrm{pH}$ values examined. 
Figure 9 shows flux and rejection data obtained with the stirred cell device for LYZ filtration at both 20 and $100 \mathrm{mM}$ ionic strengths. The data show $L Y Z$ rejection ranging from $50 \%(\mathrm{pH} 5)$ to $\sim 30 \%$ (pH 6-11) for $L Y Z$ in $20 \mathrm{mM}$ ionic strength solution. At $100 \mathrm{mM}$ ionic strength, $L Y Z$ rejection was comparatively lower, ranging from $\sim 30 \%(\mathrm{pH} 5)$ to $\sim 25 \%(\mathrm{pH} \mathrm{6-11)}$. Thus, rejection was $\mathrm{pH}$ invariant over the $\mathrm{pH}$ range $6-11$ but increased at $\mathrm{pH} 5$ (at both ionic strengths). The rejection values are higher than would be expected based on the Stoke's radius of LYZ and suggests a larger effective radius with a dependency on the solution ionic strength (Debye length). The increased rejection at $\mathrm{pH} 5$ is difficult to explain. The authors did not find in literature detailed charge distribution on $L Y Z$ as a function of $\mathrm{pH}$. However, the membrane carries a moderately negative charge at pH 5 (from streaming potential measurements) and the LYZ molecule is expected to carry a large net positive charge as the $\mathrm{pH}$ is shifted far away from the protein's pl. Hence, some LYZ adsorption onto the membrane surface may be expected which could possibly lead to 'self-rejection' of positively charged LYZ in the solution bulk by positively charged LYZ adsorbed at the membrane surface. Ghosh and Cui [8] observed greater self-rejection of LYZ at a $\mathrm{pH}$ far away from the pl. Müller et al. [27] also reported that LYZ forms a positively charged layer at the membrane surface below its pl. The permeate flux was found to be lower for the LYZ experiments compared with the BSA experiments. The permeate flux was found to be higher at the higher ionic strength, between $60-70 \mathrm{~L} / \mathrm{m}^{2} \mathrm{~h}$ for the $100 \mathrm{mM}$ solution and between $55-60 \mathrm{~L} / \mathrm{m}^{2} \mathrm{~h}$ for the $20 \mathrm{mM}$ solution. The evaluated true rejection coefficient values $\left(R_{t r}\right)$ are presented in Table 3. Between $\mathrm{pH} 6$ and $11, R_{t r}$ is around 0.5 (lying between the observed rejection values of dxt12 and dxt25 in Figure 6). At pH 5, the $R_{t r}$ is around 0.6.

The values of the evaluated mass transfer coefficients for $L Y Z$ filtration with the stirred cell are shown in Table 1. Charge shielding at higher solution ionic strength (100 mM) results in higher convective mass transfer coefficients. However, the smaller solute size may result in greater accessibility of smaller membrane pores (not accessible to the solute at $20 \mathrm{mM}$ ) and this results in greater protein transmission of $L Y Z$ at the higher ionic strength. The $\mathrm{Pe}_{m}$ for both sets of experiments is around 1.2 so the influence of ionic strength on size exclusion is better represented due to comparison on a like for like basis.

Figure 10 shows flux and rejection data obtained with the crossflow device for LYZ filtration at both 20 and $100 \mathrm{mM}$ ionic strengths. The data in Figure 10 show $\mathrm{LYZ}$ rejection ranging from $22 \%(\mathrm{pH}$ 5) to $\sim 10 \%(\mathrm{pH} \mathrm{6-11)}$ for data recorded for $L Y Z$ in the $20 \mathrm{mM}$ ionic strength solution. At $100 \mathrm{mM}$ ionic strength, LYZ rejection was slightly lower, ranging from $\sim 15 \%(\mathrm{pH} 5)$ to $\sim 6 \%(\mathrm{pH} 6-11)$. Thus, observed rejections appear to be $\mathrm{pH}$ invariant over the $\mathrm{pH}$ range 6-11 but increased moderately at $\mathrm{pH} 5$ (this effect is seen at both ionic strengths). Permeate flux was found to be higher at the high ionic strength, between 80 and $100 \mathrm{~L} / \mathrm{m}^{2} \mathrm{~h}$ for the $100 \mathrm{mM}$ solution and between 75 and $80 \mathrm{~L} / \mathrm{m}^{2} \mathrm{~h}$ for the $20 \mathrm{mM}$ solution. The $\mathrm{Pe}_{m}$ is $\sim 5.5(20 \mathrm{mM})$ and $\sim 5(100 \mathrm{mM})$ and this results in higher solute concentration at the wall thereby increasing the transmission of LYZ.

Comparing the LYZ ultrafiltration data for the stirred cell device (Figure 9) with the crossflow device (Figure 10) shows effects attributed to the type of system used for the study. LYZ rejection was observed to be notably higher for the stirred cell (low values of $\mathrm{Pe}_{m}$ ) compared with the crossflow device (high values of $\mathrm{Pe}_{m}$ ). The rejection data for the crossflow system were dominated by concentration polarisation effects. For the stirred cell system effects of ionic strength on protein rejection become apparent. The observed rejections in the stirred cell were always higher due to the higher values of the convective mass transfer coefficients compared to the laminar flow device. It is known that concentration polarisation can lead to higher protein transmission due to increased wall concentration of the partially retained solutes close to the membrane surface. This may adversely effect the solvent flux over time due to protein fouling.

As in the case of BSA filtration $\mathrm{pH}$ did not seem to have significant effect on $L Y Z$ rejection at the higher ionic strength. Only at pH 4.9 was a slight increase in rejection be observed. At the higher ionic strength, charge-shielding of the proteins results in reduction in the protein effective size [27]. In addition, less self-rejection of LYZ is anticipated in a solution environment where protein charge 
is shielded. It is therefore not surprising that LYZ permeate flux behaves differently to the flux observed for BSA. Thus, permeate flux is higher at the higher ionic strength.

\section{CONCLUSIONS}

Differences in the operating dynamics of a stirred cell and a crossflow cell manifest in differences in observed solute rejection behaviour. Characterisation of a $50 \mathrm{kDa}$ PES membrane using conventional dextran solute rejection data demonstrated a higher membrane cut-off of $75 \mathrm{kDa}$ equivalent dextran size, when the membrane was characterised using the crossflow system compared with $50 \mathrm{kDa}$ when the membrane was characterised using the stirred cell device. This is found to be due to differences in the $\mathrm{Pe}_{m}$ for the two systems. For the laminar flow system (CF), poor back-mixing of partially or completely rejected solute at the surface of the membrane results in a higher local solute concentration at the membrane wall resulting in lower observed solute rejection.

The dextran rejection data does not provide a good indication of the observed protein rejection behaviour due to the protein hydrodynamic size being a function of the solution properties (especially ionic strength). Incorporating the effects of solution properties on the protein hydrodynamic size and accounting for the hydrodynamic conditions (magnitude of $\mathrm{Pe}_{m}$ ) within the filtration system helps in understanding the effect of operating conditions on the observed solute rejection values.

Under the conditions studied, concentration polarisation was more pronounced in the crossflow device compared to the stirred cell which is significant if scale-up from a stirred cell to an industrial tangential flow device is desired. In this study, the magnitude of the wall shear stress was supposed to be similar for the two devices. In reality, this was found not to be the case with the wall shear stress for the SC $\sim 30 \mathrm{~Pa}$ compared with CF $\sim 1 \mathrm{~Pa}$. This resulted in significantly different mixing conditions within the two systems. Future work will look at the comparison of the two systems by keeping the membrane Peclet number constant.

Characterisation of the ultrafiltration membrane on the basis of dextran rejection behaviour and use for the protein separation requires an appreciation of the influence of solution environment such as ionic strength and $\mathrm{pH}$ that influence the rejection/transmission of proteins by changing the effective size of the solute. The influence of hydrodynamic conditions can be more easily quantified using the stirred cell system. Thus, the use of dead-end stirred cells provides the means to evaluate the sensitivity of the process to changes in operating conditions. This will be evaluated in greater detail in future studies.

\section{ACKNOWLEDGEMENT}

The authors wish to acknowledge the receipt of an EPSRC CASE studentship and the financial support by Diageo UK Ltd. to carry out this study. The authors would also like to express their gratitude to Microdyn-Nadir $\mathrm{GmbH}$, Germany, who kindly provided their membranes for this work. Valuable discussion and input from Yogesh Gupta is also greatly appreciated.

\section{NOMENCLATURE}

$\begin{array}{ll}a & \text { channel width }(\mathrm{m}) \\ b & \text { channel height }(\mathrm{m}) \\ C & \text { protein concentration }(\mathrm{g} / \mathrm{L}) \\ D & \text { diameter }(\mathrm{m}) \text { or diffusion coefficient }\left(\mathrm{m}^{2} / \mathrm{s}\right) \\ e & \text { elementary charge, } 1.602 \times 10^{-19}(\mathrm{C}) \\ h & \text { blade height }(\mathrm{cm})\end{array}$




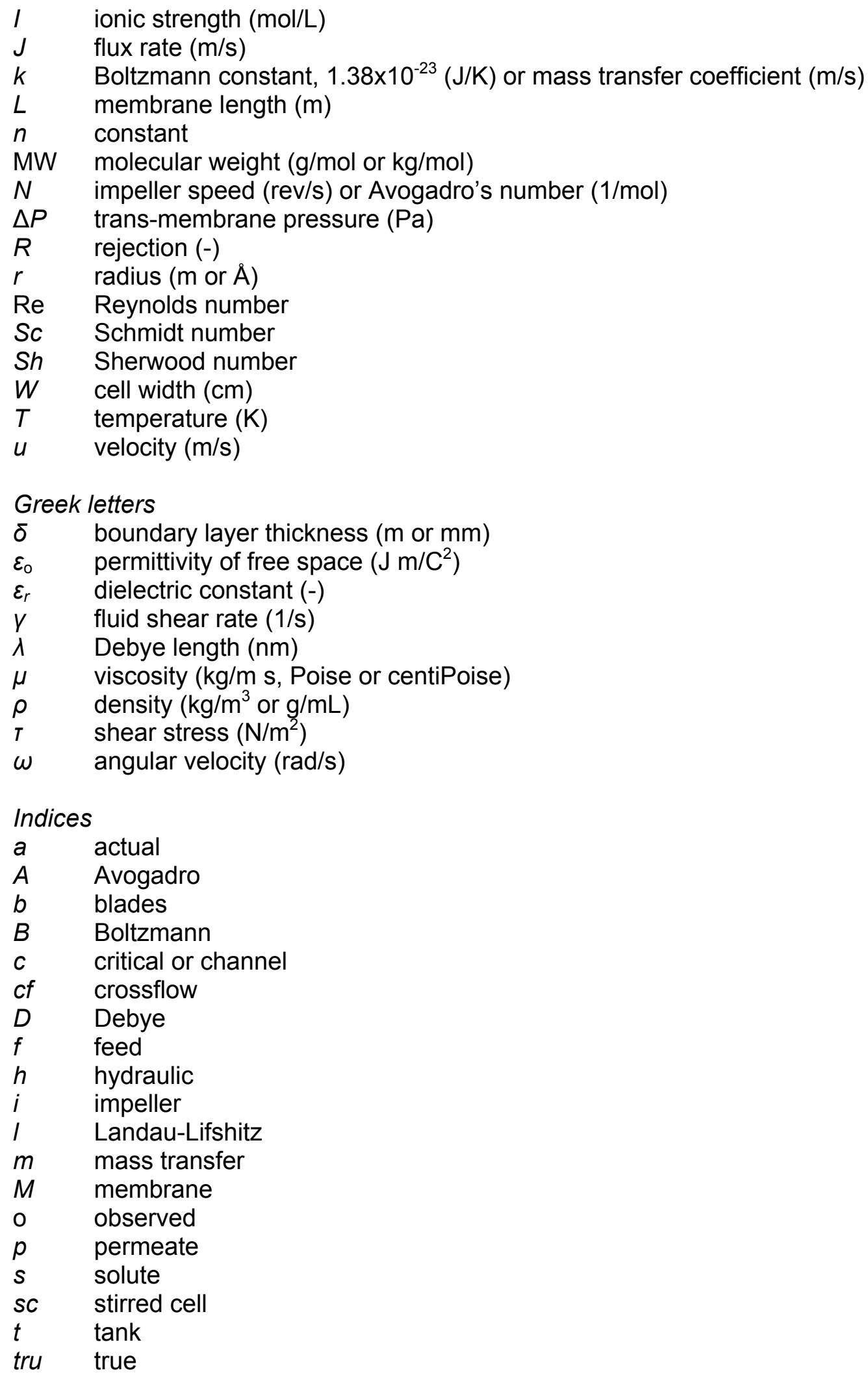

\section{REFERENCES}

1. D.B. Burns and A.L. Zydney, Effect of solution $\mathrm{pH}$ on protein transport through ultrafiltration membranes, Biotechnol. Bioeng., 64 (1999), 27-37. 
2. N. Ehsani, S. Parkinnen and M. Nyström, Fractionation of natural and model egg-white protein solutions with modified and unmodified polysulfone UF membranes, J. Membr. Sci., 123 (1997), 105-119.

3. E. Iritani, Y. Mukai and T. Murase, Separation of binary protein mixtures by ultrafiltration, Filt. and Sep., 34 (1997), 967-973.

4. M. Nyström, P. Aimar, S. Luque, M. Kulovaara and S. Metsämuuronen, Fractionation of model proteins using their physiochemical properties, Colloids Surf. A, 138 (1998), 185-205.

5. S. Saksena and A.L. Zydney, Effect of solution $\mathrm{pH}$ and ionic-strength on the separation of albumin from immunoglobulins (lgg) by selective filtration, Biotechnol. Bioeng., 43 (1994), 960 968.

6. R.H.C.M. van Eijndhoven, S. Saksena and A.L. Zydney, Protein fractionation using electrostatic interactions in membrane filtration, Biotechnol. Bioeng., 48 (1995), 406-414.

7. S. Salgin, Effects of ionic environments on bovine serum albumin fouling in a cross-flow ultrafiltration system, Chem. Eng. Technol., 30 (2007), 77-86.

8. R. Ghosh and Z.F. Cui, Fractionation of BSA and lysozyme using ultrafiltration: Effect of pH and membrane pretreatment, J. Membr. Sci., 139 (1998), 17-28.

9. R.S. Faibish, M. Elimelech and Y. Cohen, Effect of interparticle electrostatic double layer interactions on permeate flux decline in crossflow membrane filtration of colloidal suspensions: An experimental investigation, J. Colloid Interface Sci., 204 (1998), 77-86.

10. M. Nyström, P. Aimar, S. Luque, M. Kulovaara and S. Metsämuuronen, Fractionation of model proteins using their physiochemical properties, Colloids Surf. A, 138 (1998), 185-205.

11. D.B. Mosqueda-Jimenez, R.M. Narbaitz and T. Matsuura, Membrane fouling test: Apparatus evaluation, J. Environ. Eng., 130 (2004), 90-99.

12. T. Schipolowski, A. Jezowska and G. Wozny, Reliability of membrane test cell measurements, Desalination, 189 (2006), 71-80.

13. B. Tansel, J. Sager, T. Rector, J. Garland, R.F. Strayer, L. Levine, M. Roberts, M. Hummerick and J. Bauer, Significance of hydrated radius and hydration shells on ionic permeability during nanofiltration in dead end and crossflow modes, Sep. Purif. Technol., 51 (2006), 40-47.

14. V.V. Tarabara, I. Koyuncu and M.R. Wiesner, Effect of hydrodynamics and solution ionic strength on permeate flux in cross-flow filtration: Direct experimental observation of filter cake cross-sections, J. Membr. Sci., 241 (2004), 67-78.

15. A.L. Zydney and A. Xenopoulos, Improving dextran tests for ultrafiltration membranes: Effect of device format, J. Membr. Sci., 291 (2007), 180-190.

16. R.H. Perry and D.W. Green (Eds.), Perry's Chemical Engineers' Handbook, McGraw-Hill, New York, 1997.

17. S.R. Kosvintsev, G. Gasparini, R.G. Holdich, I.W. Cumming and M.T. Stillwell, Liquid-liquid membrane dispersion in a stirred cell with and without controlled shear, Ind. Eng. Chem. Res., 44 (2005), 9323-9330.

18. S. Middleman., An Introduction to Mass and Heat Transfer: Principles of Analysis and Design, Wiley, New York, 1998. 
19. L.D. Landau and E.M. Lifshitz, Fluid Mechanics, Pergamon, London, 1959.

20. N.S. Pujar and A.L. Zydney, Electrostatic effects on protein partitioning in size-exclusion chromatography and membrane ultrafiltration, J. Chromatogr. A, 796 (1998), 229-238.

21. S. Mochizuki and A.L. Zydney, Effect of protein adsorption on the transport characteristics of asymmetric ultrafiltration membranes, Biotechnol. Prog., 8 (1992), 553-561.

22. A. Mehta and A.L. Zydney, Effect of membrane charge on flow and protein transport during ultrafiltration, Biotechnol. Prog., 22 (2006), 484-492.

23. W.F. Blatt, A. Dravid, A.S. Michaels and L. Nelsen, Solute polarization and cake formation in membrane ultrafiltration: consequences, and control techniques, in Membrane Science and Technology - Industrial, Biological, and Waste Treatment Processes, Plenum Press, New York, 1970, pp.47-97.

24. K.A. Granath and B.E. Kvist, Molecular weight distribution analysis by gel chromatography on sephadex, J. Chromatogr., 28 (1967), 68-81.

25. P.G. Squire, Calculation of hydrodynamic parameters of random coil polymers from size exclusion chromatography and comparison with parameters by conventional methods, $J$. Chromatogr., 210 (1981), 433-442.

26. N.S. Pujar and A.L. Zydney, Electrostatic and electrokinetic interactions during protein transport through narrow pore membranes, Ind. Eng. Chem. Res., 33 (1994), 2473-2482.

27. C.H. Müller, G.P. Agarwal, T. Melin and T. Wintgens, Study of ultrafiltration of a single and binary protein solution in a thin spiral channel module, J. Membr. Sci., 227 (2003), 51-69. 
FIGURES AND TABLES

\begin{tabular}{|c|c|c|c|c|c|c|c|c|}
\hline Solute & Dxt1 & Dxt5 & Dxt12 & Dxt25 & Dxt50 & Dxt150 & LYZ & BSA \\
\hline $\mathrm{MW}(\mathrm{kDa})$ & 1 & 5 & 12 & 25 & 50 & 150 & 14.3 & 66.4 \\
\hline $\begin{array}{l}\text { Stokes radius } \\
(\mathrm{nm})\end{array}$ & 0.8 & 1.7 & 2.5 & 3.5 & 4.8 & 7.9 & 1.9 & 3.2 \\
\hline $\mathrm{D} \times 10^{11}\left(\mathrm{~m}^{2} / \mathrm{s}\right)$ & 27.3 & 12.8 & 8.8 & 6 & 4 & 2.2 & $5.3(20 \mathrm{mM})$ & $\begin{array}{l}4(20 \mathrm{mM}) \\
52(100 \mathrm{mM})\end{array}$ \\
\hline $\begin{array}{l}\mathrm{SC}, k_{m} \times 10^{6} \\
(\mathrm{~m} / \mathrm{s})\end{array}$ & 39 & 23 & 18 & 14 & 11 & 7 & $\begin{array}{l}13(20 \mathrm{mM}) \\
16(100 \mathrm{mM})\end{array}$ & $\begin{array}{l}11(20 \mathrm{mM}) \\
13(100 \mathrm{mM})\end{array}$ \\
\hline $\begin{array}{l}\mathrm{CF}, k_{m} \times 10^{6} \\
(\mathrm{~m} / \mathrm{s})\end{array}$ & 5.9 & 3.6 & 2.8 & 2.1 & 1.6 & 1.1 & $\begin{array}{l}4(20 \mathrm{mM}) \\
5.1(100 \mathrm{mM})\end{array}$ & $\begin{array}{l}3.3(20 \mathrm{mM}) \\
4(100 \mathrm{mM})\end{array}$ \\
\hline
\end{tabular}

Table 1: Summary of solute diffusivities, evaluated convective mass transfer coefficients. 


\begin{tabular}{|c|c|c|c|c|}
\hline & BSA & & LYZ & \\
\hline & $\mathrm{SC}^{\mathrm{C}}$ & $\mathrm{CF}^{\mathrm{d}}$ & SC & CF \\
\hline Flux $\left(\mathrm{LB}^{\mathrm{a}}-\mathrm{UB}^{\mathrm{b}}\right)\left(\mathrm{L} / \mathrm{m}^{2} \mathrm{~h}\right)$ & $60-90$ & $55-85$ & $55-80$ & $70-100$ \\
\hline Influence of $\mathrm{pH}$ on flux & & & & \\
\hline (20) $\mathrm{mM}$ & $\begin{array}{l}30 \% \text { increase } \\
\text { in flux as the } \\
\mathrm{pH} \text { increased } \\
\text { from } 5 \text { to } 8.5\end{array}$ & $\begin{array}{l}15 \% \text { increase } \\
\text { in flux as the } \\
\mathrm{pH} \text { increased } \\
\text { from } 5 \text { to } 8.5\end{array}$ & invariant & $\begin{array}{l}\sim 10 \% \text { increase in } \\
\text { flux as the } \mathrm{pH} \\
\text { increased from } 5 \\
\text { to } 8.5\end{array}$ \\
\hline (100) $\mathrm{mM}$ & $\begin{array}{l}\sim 20 \% \\
\text { increase in } \\
\text { flux as the } \\
\text { pH increased } \\
\text { from } 5 \text { to } 8.5\end{array}$ & $\begin{array}{l}\sim 20 \% \\
\text { increase in } \\
\text { flux as the } \mathrm{pH} \\
\text { increased } \\
\text { from } 5 \text { to } 8.5\end{array}$ & invariant & $\begin{array}{l}\sim 20 \% \text { increase in } \\
\text { flux as the } \mathrm{pH} \\
\text { increased from } 5 \\
\text { to } 8.5\end{array}$ \\
\hline $\begin{array}{l}\text { Influence of lonic } \\
\text { strength (mM) on flux }\end{array}$ & $(20)>(100)$ & $\begin{array}{l}(20)>(100) \\
\text { (marginal) }\end{array}$ & $(100)>(20)$ & $(100)>(20)$ \\
\hline Influence & rejection & & & \\
\hline (20) $\mathrm{mM}$ & $\begin{array}{l}\text { Invariant, } \\
\sim 10 \% \\
\text { change } \\
\text { (increase) } \\
\text { over the pH } \\
\text { range } 5-8.5\end{array}$ & $\begin{array}{l}\text { Invariant, } \\
\sim 10 \% \text { change } \\
\text { (increase) } \\
\text { over the } \mathrm{pH} \\
\text { range } 5-8.5\end{array}$ & $\begin{array}{l}\text { Almost } \\
\text { invariant } \\
\text { between pH 6- } \\
11(\sim 30 \%) \text {, but } \\
\text { higher at pH } 5 \\
(\sim 50 \%)\end{array}$ & $\begin{array}{l}\text { Almost invariant } \\
\text { between pH } 6-11 \\
(\sim 10 \%), \text { but higher } \\
\text { at pH } 5(\sim 20 \%)\end{array}$ \\
\hline (100) mM & $\begin{array}{l}\text { Invariant, } \\
\sim 5 \% \text { change } \\
\text { (decrease) } \\
\text { over the } \mathrm{pH} \\
\text { range } 5-8.5\end{array}$ & $\begin{array}{l}\text { Invariant, } \\
\sim 5 \% \text { change } \\
\text { (increase) } \\
\text { over the } \mathrm{pH} \\
\text { range } 5-8.5\end{array}$ & $\begin{array}{l}\text { Almost } \\
\text { invariant } \\
\text { between pH 6- } \\
11(\sim 25 \%) \text {, but } \\
\text { higher at pH } 5 \\
(\sim 30 \%)\end{array}$ & $\begin{array}{l}\text { Almost invariant } \\
\text { between pH } 6-11 \\
(<10 \%) \text {, but higher } \\
\text { at pH } 5(\sim 15 \%)\end{array}$ \\
\hline $\begin{array}{l}\text { Influence of lonic } \\
\text { strength }(\mathrm{mM}) \text { on protein } \\
\text { rejection }\end{array}$ & $\begin{array}{l}(100)>(20) \\
(20)<75 \% \\
(100)>85 \%\end{array}$ & $\begin{array}{l}\text { Almost } \\
\text { invariant } \\
(20)>85 \% \\
(100)>95 \%\end{array}$ & $\begin{array}{l}(20)>(100) \\
(20) 30-60 \% \\
(100) 20-30 \%\end{array}$ & $\begin{array}{l}\text { Almost invariant } \\
(20)>(100) \\
(20) 10-20 \% \\
(100) 5-15 \%\end{array}$ \\
\hline Rejection range: & $\sim 65$ to $90 \%$ & $\sim 85$ to $100 \%$ & $\sim 20$ to $50 \%$ & $\sim 5$ to $25 \%$ \\
\hline
\end{tabular}

${ }^{a}$ LB: Lower Bound; ${ }^{b} U B$ : Upper Bound; ' $S$ tirred cell; ${ }^{d}$ Crossflow cell

Table 2: Summary of protein ultrafiltration results comparing data for stirred cell and crossflow mode of operation. 


\begin{tabular}{|l|c|c|c|c|c|}
\hline $\begin{array}{l}\text { Filtration } \\
\text { apparatus }\end{array}$ & $\mathrm{pH}$ & $\begin{array}{c}\text { True rejection, } \\
R_{t r}(-) \\
\text { BSA 20 mM }\end{array}$ & $\begin{array}{c}\text { True rejection, } \\
R_{t r}(-) \\
\text { BSA 100 mM }\end{array}$ & $\begin{array}{c}\text { True rejection, } \\
R_{t r}(-) \\
\text { LYZ 20 mM }\end{array}$ & $\begin{array}{c}\text { True rejection, } \\
R_{t r}(-) \\
\text { LYZ 100 mM }\end{array}$ \\
\hline SC & 11.0 & $\mathrm{~N} / \mathrm{A}$ & 0.00 & 0.59 & 0.51 \\
SC & 8.4 & 0.97 & 0.97 & 0.64 & 0.50 \\
SC & 7.0 & 0.95 & 0.98 & 0.68 & 0.54 \\
SC & 6.0 & 0.95 & 0.97 & 0.68 & 0.52 \\
SC & 4.9 & 0.94 & 0.98 & 0.77 & 0.61 \\
CF & 8.4 & 1.00 & 1.00 & 0.96 & 0.93 \\
CF & 7.0 & 1.00 & 1.00 & 0.97 & 0.94 \\
CF & 6.0 & 1.00 & 1.00 & 0.97 & 0.91 \\
CF & 4.9 & 1.00 & 1.00 & 0.98 & 0.93 \\
\hline
\end{tabular}

Table 3: True rejection coefficients for the stirred cell and crossflow apparatus at two different ionic strengths (20 and $100 \mathrm{mM})$.

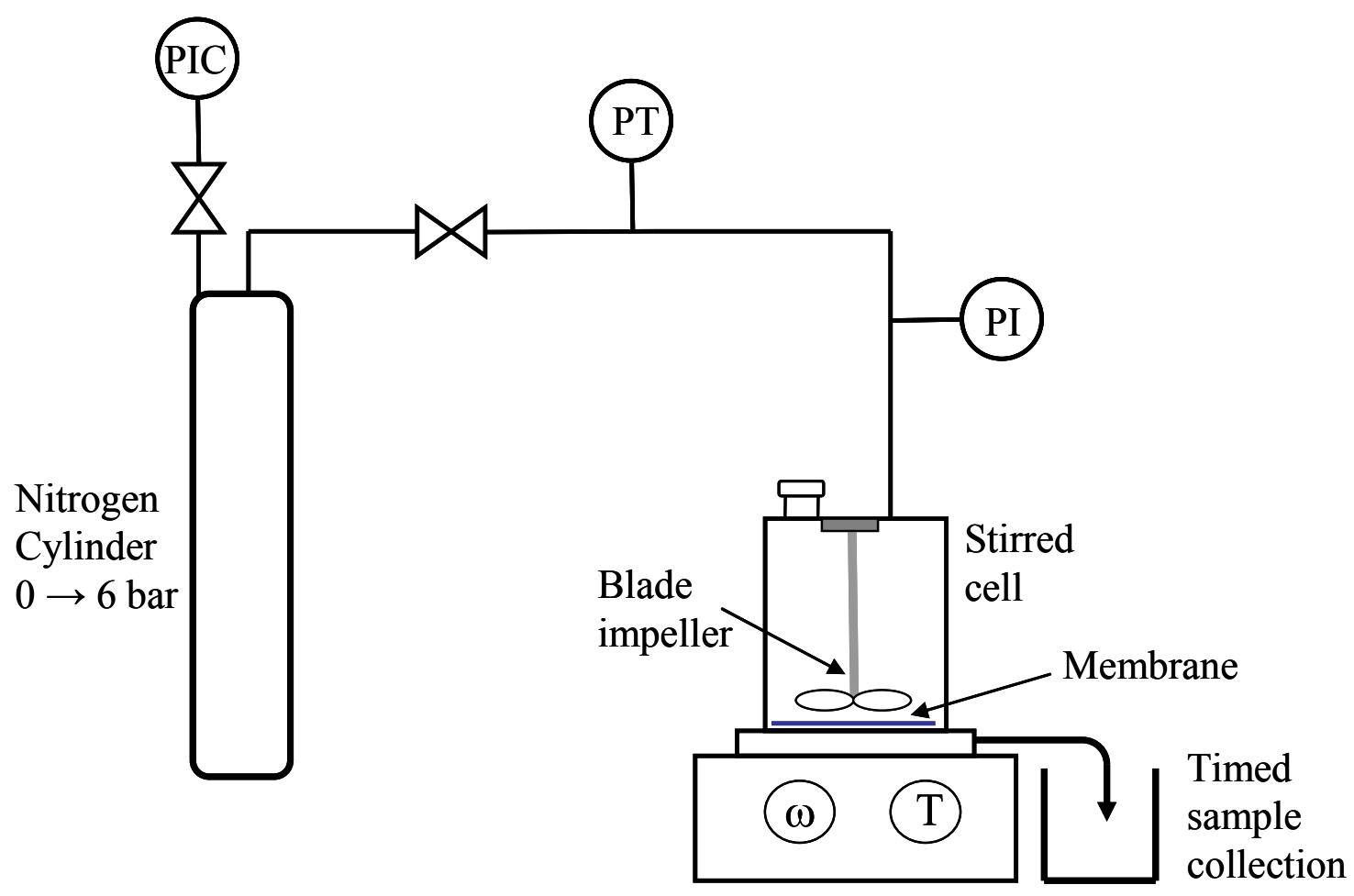

Figure 1: Schematic diagram of the stirred cell apparatus. 


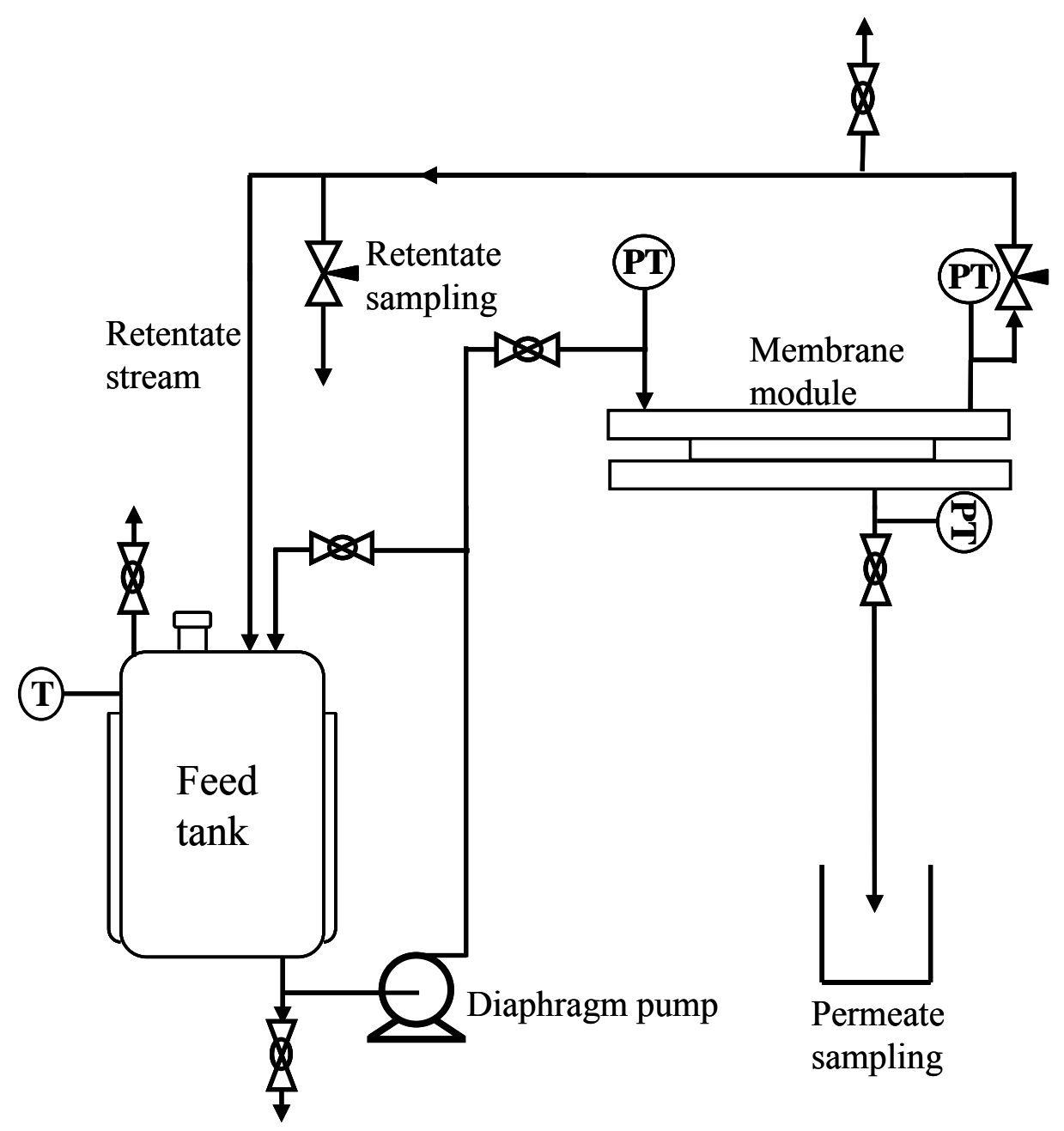

Figure 2: Schematic diagram of the crossflow apparatus.

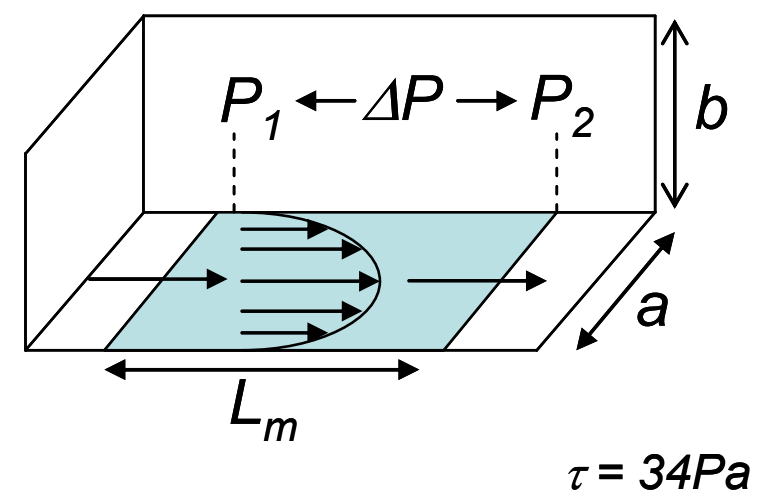

Figure 3: Force balance across the membrane in the crossflow module $(a=30 \mathrm{~mm}, b=2 \mathrm{~mm}, L=$ $30 \mathrm{~mm})$. 


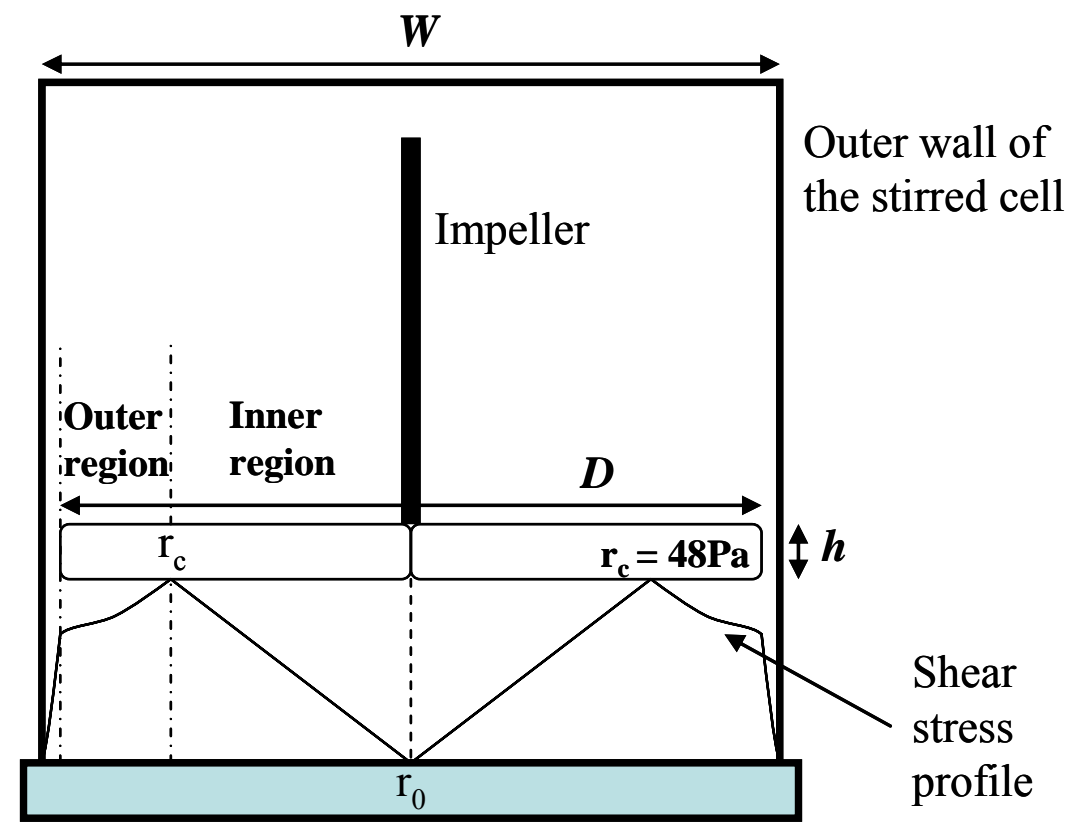

Figure 4: Shear stress variation along the impeller length.

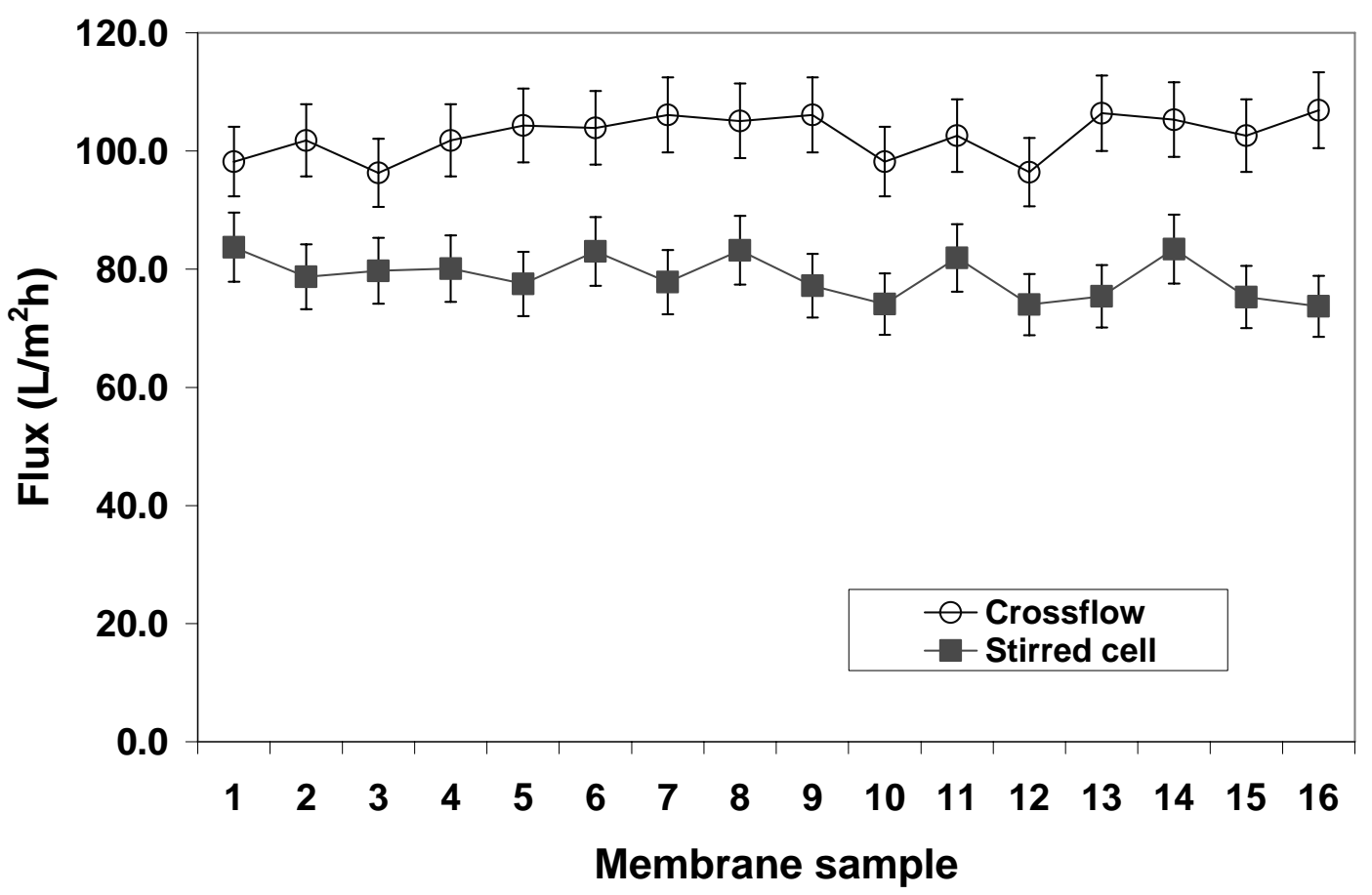

Figure 5: Flux variation for the $50 \mathrm{kDa}$ polyethersulfone membranes (TMP $25 \mathrm{kPa}$ ). 


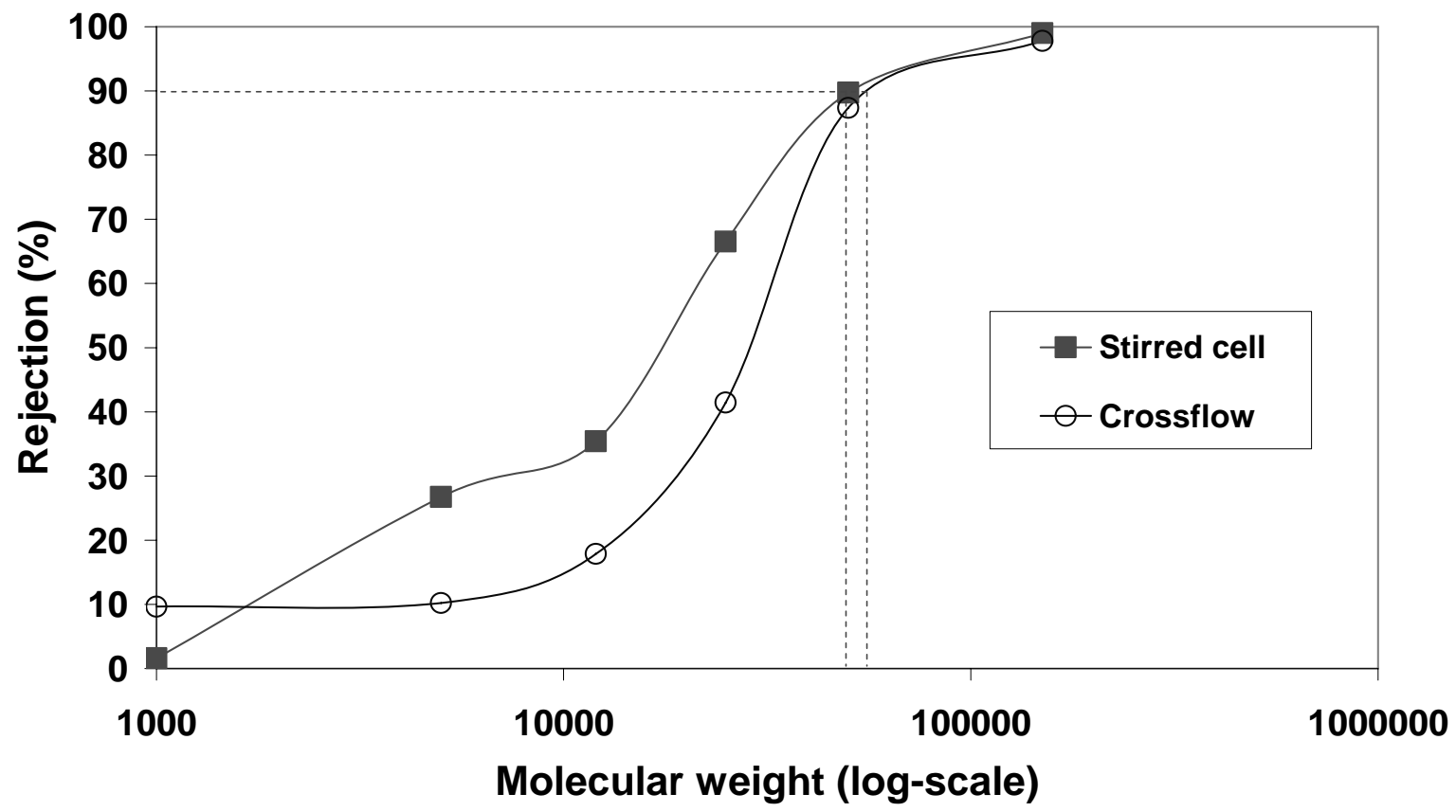

Figure 6: Dextran rejection: comparison between the stirred cell and the crossflow module (for a 50 kDa membrane, TMP $25 \mathrm{kPa}$ ).

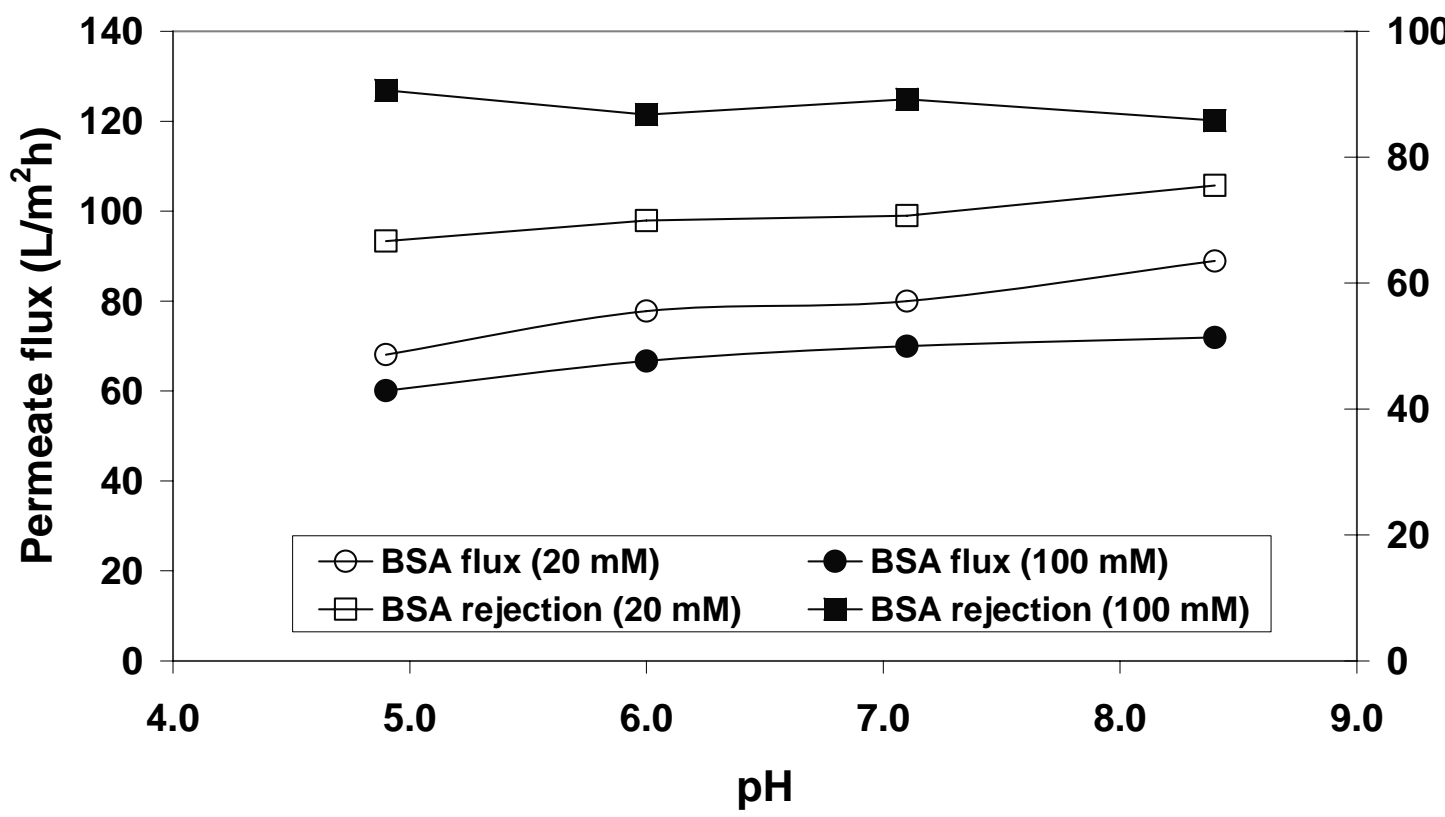

Figure 7: Flux and protein rejection vs. $\mathrm{pH}$ for BSA with the stirred cell. Feed concentration $0.5 \mathrm{~g} / \mathrm{L}$ and $\mathrm{pl}$ of $\mathrm{BSA}=\sim 4.9$ (for a $50 \mathrm{kDa}$ membrane, TMP $25 \mathrm{kPa}$ ). 


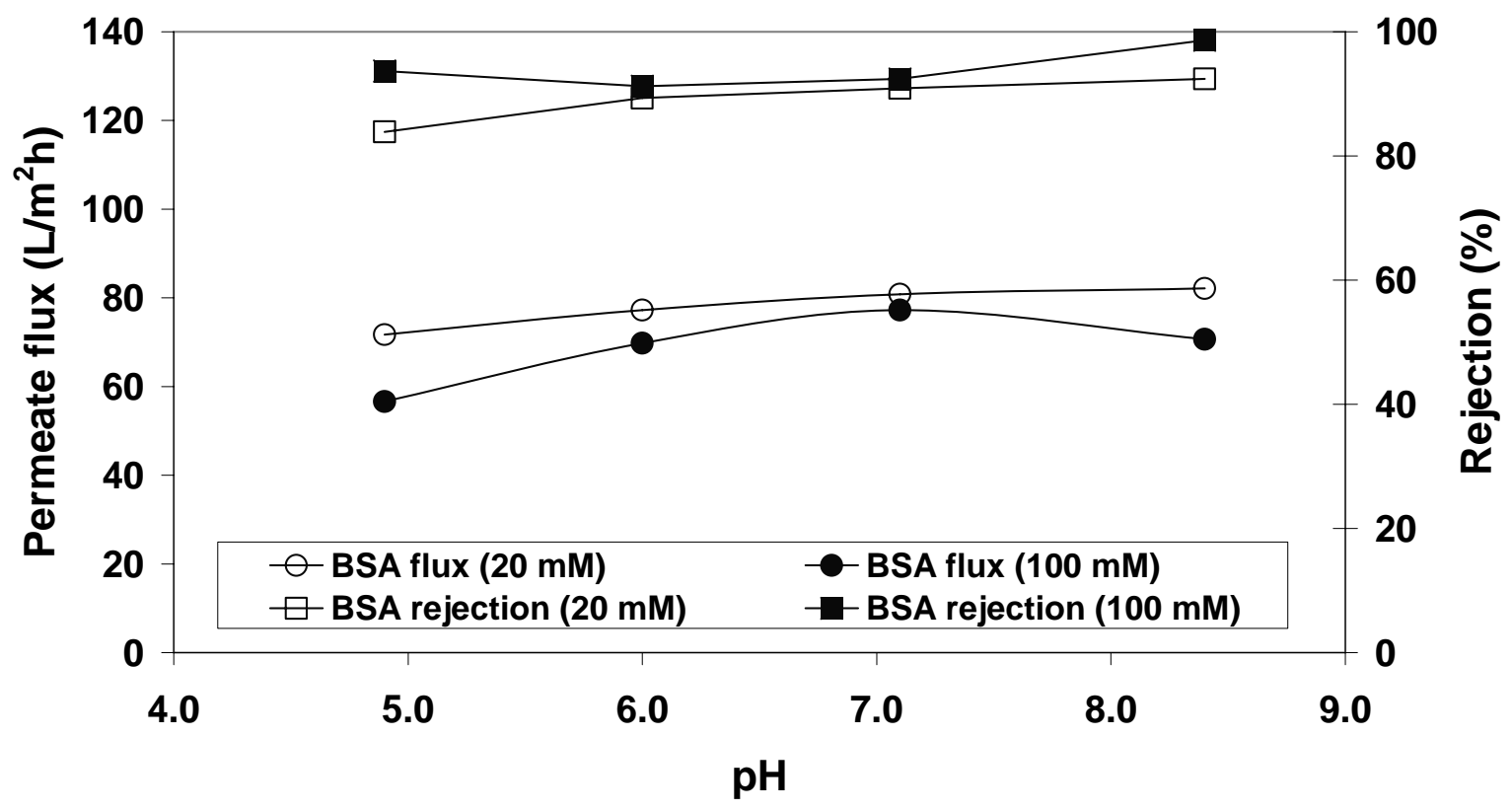

Figure 8: Flux and rejection vs. $\mathrm{pH}$ for BSA with the crossflow module. Feed concentration $0.5 \mathrm{~g} / \mathrm{L}$ and $\mathrm{pl}$ of $\mathrm{BSA}=\sim 4.9$ (for a $50 \mathrm{kDa}$ membrane, TMP $25 \mathrm{kPa}$ ).

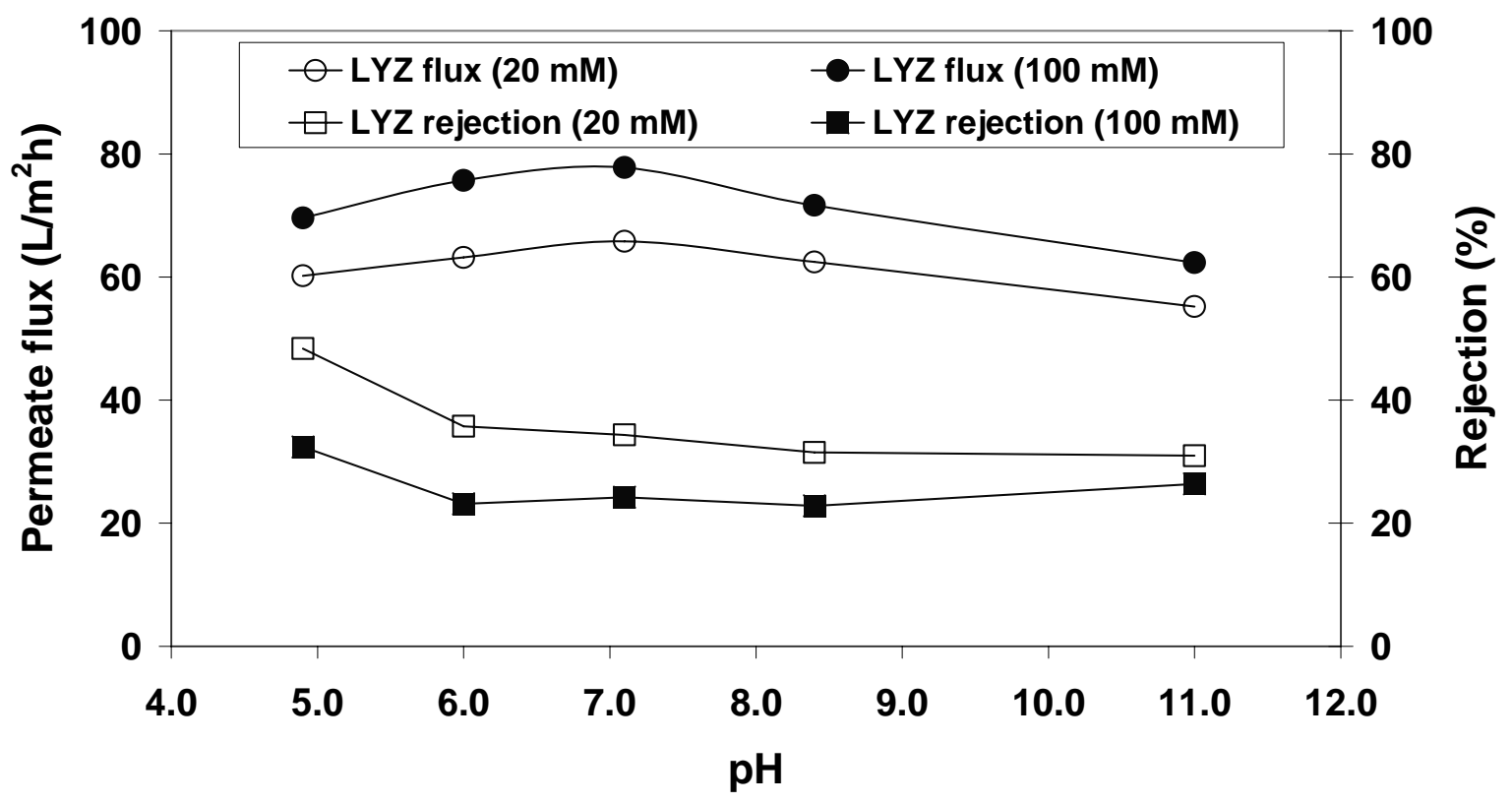

Figure 9: Flux and rejection vs. pH for $L Y Z$ with the stirred cell. Feed concentration $0.5 \mathrm{~g} / \mathrm{L}$ and $\mathrm{pl}$ of $L Y Z=\sim 11.0$ (for a $50 \mathrm{kDa}$ membrane, TMP $25 \mathrm{kPa}$ ). 


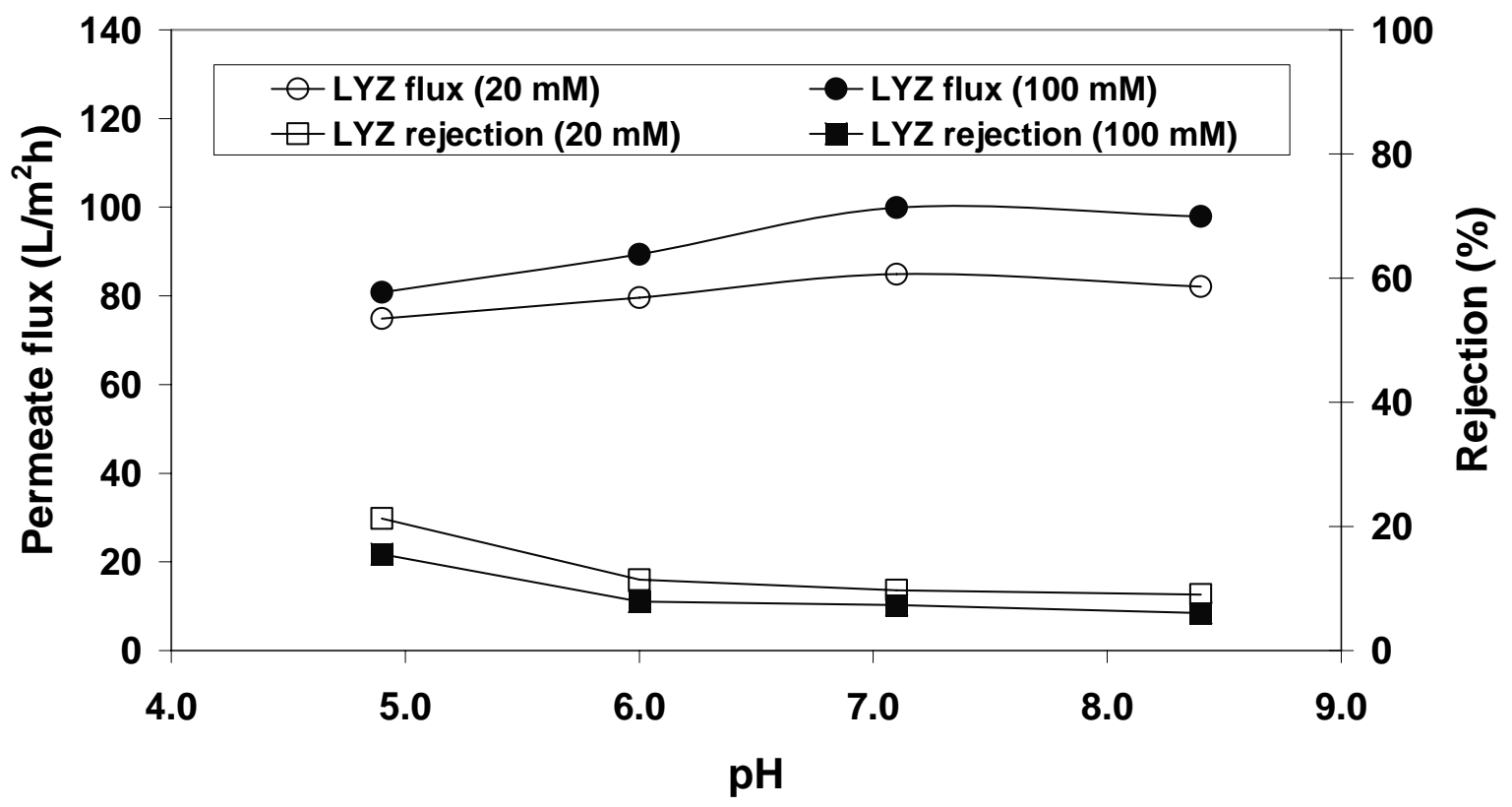

Figure 10: Flux and rejection vs. pH for LYZ with the crossflow module. Feed concentration $0.5 \mathrm{~g} / \mathrm{L}$ and pl of $L Y Z=\sim 11.0$ (for a $50 \mathrm{kDa}$ membrane, TMP $25 \mathrm{kPa}$ ). 